\title{
Behavior of high performance artificial lightweight aggregate concrete reinforced with hybrid fibers
}

\author{
Wasan Khalil ${ }^{1 *}$, Hisham Ahmed ${ }^{1}$, and Zainab Hussein ${ }^{2}$ \\ ${ }^{1}$ professor in the Building and Construction Engineering Department, University of Technology, Baghdad, Iraq \\ 2 lecturer in College of Engineering, Al Mustansiriyah University, Baghdad, Iraq
}

\begin{abstract}
In this investigation, sustainable High Performance Lightweight Aggregate Concrete (HPLWAC) containing artificial aggregate as coarse lightweight aggregate (LWA) and reinforced with mono fiber, double and triple hybrid fibers in different types and aspect ratios were produced. High performance artificial lightweight aggregate concrete mix with compressive strength of $47 \mathrm{MPa}$, oven dry density of $1 \wedge \uparrow \wedge \mathrm{kg} / \mathrm{m} 3$ at 28 days was prepared. The Fibers used included, macro hooked steel fiber with aspect ratio of 60 (type S1), macro crimped plastic fiber (P) with aspect ratio of 63, micro steel fiber with aspect ratio of 65 (type S), and micro polypropylene fiber (PP) with aspect ratio of 667. Four HPLWAC mixes were prepared including, one plain concrete mix (without fiber), one mono fiber reinforced concrete mixes (reinforced with plastic fiber with $0.75 \%$ volume fraction), one double hybrid fiber reinforced concrete mixes $(0.5 \%$ plastic fiber $+0.25 \%$ steel fiber type $\mathrm{S})$, and a mix with triple hybrid fiber $(0.25 \%$ steel fiber type $\mathrm{S} 1+0.25 \%$ polypropylene fiber $+0.25 \%$ steel fiber type $\mathrm{S}$ ). Fresh (workability and fresh density) and hardened concrete properties (oven dry density, compressive strength, ultrasonic pulse velocity, splitting tensile strength, flexural strength, static modules of elasticity, thermal conductively, and water absorption) were studied. Generally, mono and hybrid (double and triple) fiber reinforced HPLWAC specimens give a significant increase in splitting tensile strength and flexural strength compared with plain HPLWAC specimens. The percentage increases in splitting tensile strength for specimens with mono plastic fiber are, $20.8 \%, 31.9 \%, 36.4 \%$ and $41 \%$, while the percentage increases in flexure strength are $19.5 \%$, $37 \%, 33.9 \%$ and $34.2 \%$ at $7,28,60,90$ days age respectively relative to the plain concrete. The maximum splitting tensile and flexure strengths were recorded for triple hybrid fiber reinforced HPLWAC specimens. The percentage increases in splitting tensile strength for triple hybrid fiber reinforced specimens are 19.5\%, $37 \%, 33.9 \%$ and $34.2 \%$, while the percentage increases in flexure strength are $50.5 \%, 62.4 . \%, 66.8 \%$ and $62.2 \%$ at $7,28,60$ and 90 days age respectively relative to the plain concrete specimens.
\end{abstract}

Keywords: Artificial Lightweight Aggregate, Plastic Fiber, Hybrid Fiber, High Performance LWA.

\section{Introduction}

High performance structural lightweight concrete (HPSLWC) is an advanced in concrete technology which has the properties of High Performance Concrete (HPC) and Lightweight Concrete (LWC) such as, high strength, low permeability, low density, and high thermal insulation properties which are appropriate for many applications.

High performance lightweight concrete typically has a compressive strength from $34-69 \mathrm{MPa}$ and an air dry density not exceeding $2000 \mathrm{~kg} / \mathrm{m}^{3}[1,2]$.

Lightweight Aggregate (LWA) used in concrete reduces the weight of different structural members which leads to a decrease in the load transmitted to the foundations, and less work and efforts are required to transport these members. The occurrence of voids and pores in LWA provides good thermal and acoustic insulating properties and a good fire resistance to concrete [3].

In Iraq, local natural LWA is very limited, such as porcelinite aggregate. The large consumption of natural lightweight aggregate leads to production and use of artificial lightweight aggregate, also the use of waste material as lightweight aggregate is the main aim of many researchers. Artificial lightweight aggregate can be produced from a wide variety of raw material and production procedures [4].

Several investigations have been carried out to study the influence of mono plastic fiber, polypropylene, and

Corresponding author: wasan1959@yahoo.com 
steel fiber on properties of artificial lightweight aggregate concrete $[5,6]$. Very little works have been done to investigate the properties of hybrid fiber reinforced lightweight concrete containing natural or expanded clay lightweight aggregate.

The behavior of hybrid fiber high strength lightweight aggregate was investigated by Daneti and Wee [7]. Hooked end macro steel fiber $(30 \mathrm{~mm}$ length with aspect ratio of 55), straight micro steel fiber (12mm length and aspect ratio of $120 \mathrm{~mm}$ ), and micro polypropylene fiber (12mm length with aspect ratio of 109) were used. The concrete mixes containing mono macro steel fiber, double hybrid fiber $(0.3 \%$ macro steel fiber $+0.3 \%$ polypropylene fiber) and triple hybrid fiber $(0.2 \%$ macro steel fiber + $0.2 \%$ micro steel fiber $+0.2 \%$ polypropylene fiber) with constant total fiber volume fraction of $0.6 \%$. Coarse lightweight expanded clay aggregate was used. The compressive strength of single and hybrid fiber showed almost equal or slightly lower strength compared with plain lightweight aggregate concrete. However, splitting and flexural tensile strengths of single and hybrid fiber were increased in the range of $16 \%-52 \%$ and $1 \%-28 \%$ respectively compared to plain LWAC. Lightweight aggregate concrete containing mono and triple fiber showed higher splitting and flexural strengths when compared with double hybrid fibers.

Widodo et al. [8] examined the effect of hybrid polypropylene-steel fiber on properties of lightweight concrete made of pumice breccia as coarse aggregate. Monofilament Polypropylene with $12 \mathrm{~mm}$ length and 18 $\mu \mathrm{m}$ diameter and macro hooked end steel fiber with 60 $\mathrm{mm}$ length and $0.75 \mathrm{~mm}$ diameter were used. Fiber addition was done using fixed polypropylene fiber volume fraction of $0.1 \%$ and different steel fiber additions of $0.0 \%, 0.5 \%, 1.0 \%, 1.5 \%$, and $2.0 \%$ by volume into the mixture. Different properties including density, compressive strength, modulus of elasticity, splitting tensile strength, modulus of rupture and the flexural load-displacement behavior of the lightweight aggregate concrete with hybrid fiber addition were studied. The results demonstrate that the addition of steel fiber to LWAC causes a decrease in the workability but the density increased. The compressive strength and modulus of elasticity of lightweight concrete increased. The splitting tensile strength and modulus of rupture for hybrid LWAC with $0.1 \%$ polypropylene $+1.5 \%$ steel fiber improved by about $222.28 \%$ and $187.47 \%$ respectively. Flexural performance is much better in hybrid fiber reinforced LWAC of $0.1 \%$ polypropylene $+1.5 \%$ steel compared to the plain concrete mixes.

\section{Research significance}

Research significance can be summarized as follows:

- Producing high performance LWAC containing artificial sustainable LWA produced from locally available materials and studying its properties.

- Investigate the effect of inclusion mono and hybrid fibers on the properties of the produced high performance LWAC.

\section{Experimental programs}

\subsection{Materials}

- Ordinary Portland cement (Type I) from Bazian Company in Iraq was used. Test results show that the adopted cement satisfies the Iraqi Specifications No. 5/1984 [9].

- Normal weight natural sand with maximum size of $4.75 \mathrm{~mm}$ was used in this investigation. The results demonstrate that the grading of the sand, physical properties and sulfate content are within the requirements of the Iraqi Specifications No. 45/ 1984 [10].

- An artificial lightweight aggregate was produced from bentonite clay and sodium silicate liquid waste from glass plant through this study, as mentioned by the research (11). Bentonite clay was screened through $75 \mu \mathrm{m}$ sieve. Many trials were carried out to select the proper amount of sodium silicate that produces a paste of adequate plasticity. Sodium silicate liquid waste with 50\% mixing ratio by weight (clay: sodium silicate, 1:1) was selected. The clayey paste was rounded by handed to form balls, then they were left to dry at laboratory temperature for 24 hours to avoid the formation of shrinkage cracks. The clayey balls were then dried in an oven for 24 hours at $100{ }^{\circ} \mathrm{C}$ to ensure complete drying, and then they were burned at different high temperatures. It was found that burning these balls at temperature between $750-800{ }^{\circ} \mathrm{C}$ for two hours produces lightweight aggregate with properties conforming to ASTM C 330 Specifications [12]. Finally, the furnace was opened and the specimens were left inside the furnace until they were cooled to laboratory temperature. The clayey balls were crushed manually to smaller size by means of a hammer, and then screened on standard sieve series in order to prepare lightweight aggregate with grading which conforms to ASTM C 330 Specifications [12]. Table 1 shows the properties of the produced lightweight aggregate.

Table 1. Properties of the produce lightweight aggregate [13]

\begin{tabular}{|l|l|}
\hline Properties Specification & Test Results \\
\hline Specific gravity ASTM C127 [13] & 1.53 \\
\hline Absorption \% $\quad$ ASTM C127 [13] & 12.9 \\
\hline $\begin{array}{l}\text { Dry loose unit weight, ASTM 29/C29M[14] } \\
\mathrm{kg} / \mathrm{m}^{3}\end{array}$ & $538.22 * *$ \\
\hline $\begin{array}{l}\text { Dry rodded unit weight, ASTM 29/C29M [14] } \\
\mathrm{kg} / \mathrm{m}^{3}\end{array}$ & 543.21 \\
\hline $\begin{array}{l}\text { Aggregate crushing BS 812-part 110-1990 [15] } \\
\text { value, } \% \text { ) }\end{array}$ & 51.6 \\
\hline $\begin{array}{l}\text { Sulfate content } \\
\text { as SO } \mathrm{S}_{3} \text { ), \% }\end{array}$ & 0.97 \\
$* \begin{array}{l}\text { Physical analysis was conducted by National Center for } \\
\text { Construction Laboratories and Researches (NCCLR) } \\
* * \text { Within the limit of ASTM C 330, } \leq 880 \mathrm{~kg} / \mathrm{m}^{3}\end{array}$ \\
\hline
\end{tabular}

- Two types of high performance LWAC admixtures were used in this work including, chemical admixture based on modified Polycarboxylic ether (Sika Viscocrete - 5930). It is a third generation superplasticizer meeting the requirements of ASTM 
C494M / 04[17] types F and silica fume produced by Sika Company. The results indicate that the silica fume used satisfy the physical and chemical requirements of the ASTM C1240 [18].

- Four types of fiber were used in this investigation including:

a- Macro hooked steel fibers (type $S_{1}$ ) with $30 \mathrm{~mm}$ length and $0.5 \mathrm{~mm}$ diameter (aspect ratio $1 / \mathrm{d}=60$ ), the ultimate tensile strength for individual fibers is $1180 \mathrm{MPa}$ and density is $7800 \mathrm{~kg} / \mathrm{m}^{3}$.

b- Straight steel fibers (type S) with $13 \mathrm{~mm}$ in length and $0.2 \mathrm{~mm}$ in diameter (aspect ratio $1 / \mathrm{d}=65$ ), the ultimate tensile strength for individual fibers is 1180 $\mathrm{MPa}$ and the density is $7800 \mathrm{~kg} / \mathrm{m}^{3}$.

c- Crimped plastic fiber (P) with $50 \mathrm{~mm}$ length, $0.8 \mathrm{~mm}$ diameter (aspect ratio $1 / \mathrm{d}=63$ ), and minimum tensile strength between 250-350 MPa.

d- Micro polypropylene fiber (PP) with $12 \mathrm{~mm}$ length, 18 micron diameter (aspect ratio $1 / \mathrm{d}=677$ ), and minimum tensile strength of $350 \mathrm{MPa}$.

\subsection{Concrete mixes}

Control LWAC mix (plain) and many of LWAC mixes reinforced with mono and hybrid fiber was prepared in this work. Table 2 explains the details of concrete mixes studied in this work.

Table 2. Details of lightweight aggregate concrete mixes

\begin{tabular}{|c|c|c|c|c|c|}
\hline \multirow{2}{*}{$\begin{array}{c}\text { Mix } \\
\text { Symb } \\
\text { ol }\end{array}$} & \multicolumn{4}{|c|}{ Fiber Volume Fraction (\%) } & \multirow{6}{*}{$\begin{array}{c}\text { Mix proportion } \\
\text { 1:1.18:0.73 by weight } \\
\text { (Cement:Sand:LWA), } \\
\text { Cement Content } 550 \\
\mathrm{~kg} / \mathrm{m}^{3}, \mathrm{w} / \mathrm{c}=0.25, \\
\text { HRWRA }=3 \mathrm{~L} / 100 \mathrm{~kg} \text { of } \\
\text { cement, silica fume } 10 \% \\
\text { as a replacement, by } \\
\text { weight of cement }\end{array}$} \\
\hline & $\mathrm{S}_{1}$ & $\mathrm{P}$ & $\mathrm{S}$ & $\mathrm{PP}$ & \\
\hline MAR & $\cdot$ & $\cdot$ & $\cdot$ & $\cdot$ & \\
\hline MAP & $\cdot$ & $\cdot .75$ & 0 & 0 & \\
\hline $\mathrm{MAH}_{4}$ & 0 & 0.50 & 0.25 & 0 & \\
\hline $\mathrm{MAH}_{5}$ & $\cdot .25$ & $\cdot$ & 0.25 & 0.25 & \\
\hline
\end{tabular}

\subsection{Preparation, casting and curing of specimens.}

After conducting workability test (slump and inverted slump cone tests) the concrete specimens were prepared by casting the concrete in different standard molds. The molds were well cleaned and oiled before casting of concrete to avoid the adhesion of hardened concrete to the internal surfaces of the molds. The fresh concrete was placed in the molds with layers according to the standard specifications for each test and compaction by means of vibration table. The top layers of concrete specimens had been smoothed by steel trowel, and then the specimens were covered with nylon sheets for 24 hours to prevent the evaporation of water. After that the concrete specimens were demoulded and fully immersed in tap water until the time of testing.

\subsection{Experimental tests}

The following experimental tests were carried out to investigate the effect of artificial LWA on some properties of HPLWAC reinforced with fiber:

- Slump test according of ASTM C-143 [19]
- Fresh density test according ASTM C 567-05a [20].

- Inverted slump cone test according to ASTM C995[21].

- Oven dry density test according to ASTM C 567-05a [20] (using $150 \times 300 \mathrm{~mm}$ cylindrical specimens).

- Compressive strength test according to B.S. 1881[22] (using $100 \mathrm{~mm}$ cube specimens).

- Splitting tensile strength test according to ASTM C496 [23](using 100×200 mm cylindrical specimens).

- Flexural tensile strength test according to ASTM C78 [24] (using $100 \times 100 \times 400 \mathrm{~mm}$ prism specimens).

- Static Modulus of Elasticity test according to ASTM C469 [25] (using 150×300 mm cylindrical specimens).

- Ultrasonic pulse velocity test according to ASTM C597 [26] ( using $100 \mathrm{~mm}$ cube specimens).

- Thermal conductivity test was carried out on specimens with dimensions $200 \times 100 \times 100 \mathrm{~mm}$ (length $\times$ width $\times$ thickness).

- Water absorption test according to ASTM C642 [27] (using $100 \mathrm{~mm}$ cube specimens).

\section{Results and Discussion}

\subsection{Selection of mix proportions for high performance LWAC}

Reference lightweight aggregate concrete mix was designed in accordance with ACI 211.2 [28] without any admixtures with compressive strength of $20 \mathrm{MPa}$ at age 28 days. The mix proportion of this mix is 1:1.18:0.73 (cement: sand: LWA) by weight, w/c ratio of 0.42 to have slump value of $100 \pm 5 \mathrm{~mm}$, and cement content of $550 \mathrm{~kg} / \mathrm{m}^{3}$. Several trial mixes were achieved in order to select the optimum silica fume content and the optimum dosage of superplasticizer, while $\mathrm{w} / \mathrm{c}$ ratio was modified to have the same slump value of the plain mix (without fiber). The results demonstrate that the optimum dosage of superplasticizer was 3.0 Liter per $100 \mathrm{~kg}$ of cement. The oven dry density and the compressive strength at 28 days age for the selected reference mix are $1815 \mathrm{~kg} / \mathrm{m}^{3}$ and $41.6 \mathrm{MPa}$ respectively. The details of the trial concrete mixes with different dosages of superplasticizer are shown in Table [3]. Different dosages of silica fume as a partial replacement by weight of cement $(5 \%, 8 \%$, and $10 \%)$ were used with the selected mix containing the optimum dosage of superplasticizer. Table [4] shows the effect of silica fume content on workability, compressive strength and density of LWAC mixes. It can be noticed that the workability of the concrete mix is slightly decreased with the increase of silica fume content. This is because of the high surface area of very fine particles of silica fume which leads to absorbed water. The compressive strength and oven dry density of the selected mix containing $10 \%$ silica fume as a replacement by weight of cement and 3 liter of superplasticizer $/ 100 \mathrm{~kg}$ of cement are $47 \mathrm{~N} / \mathrm{mm}^{2}$ and $1828 \mathrm{~kg} / \mathrm{m}^{3}$ respectively at 28 days age.

\subsection{Workability}


The workability test results including slump test and inverted slump cone test are shown in Table [5]. The slump test did not give accurate results for workability of fiber reinforced concrete mixes [29]; hence inverted slump cone test is recommended for this type of mixes. Generally, the results indicate that the inclusion of fibers reduces the workability. This is due to the large surface area of fibers that increases the viscosity of the mixtures [30]. All HPLWAC mixes reinforced with fibers were produced without any fibers balling. Despite the reduction in workability, visible inspections show that the addition of fibers to HPLWAC enhances the uniformity and stability for fresh mixes. This is because fibers can make network structure in fresh concrete that can effectively restrain the segregation of LWA; this was also indicated by Libre et al. [31].

Table 3. Details of the trial mix with different dosages of HRWRA

\begin{tabular}{|c|c|c|c|c|c|}
\hline \multirow[t]{2}{*}{$\begin{array}{c}\mathrm{w} / \mathrm{c} \\
\text { Ratio }\end{array}$} & \multirow{2}{*}{$\begin{array}{c}\text { HRWRA } \\
\text { (L/100 } \\
\text { kg of } \\
\text { cement) }\end{array}$} & \multirow[t]{2}{*}{$\begin{array}{l}\text { Slump } \\
(\mathrm{mm})\end{array}$} & \multirow{2}{*}{$\begin{array}{l}\text { Oven } \\
\text { dry } \\
\text { density } \\
\mathrm{kg} / \mathrm{m}^{3}\end{array}$} & \multicolumn{2}{|c|}{$\begin{array}{l}\text { Compressive } \\
\text { strength } \\
\text { (MPa) }\end{array}$} \\
\hline & & & & $\begin{array}{c}7 \\
\text { days }\end{array}$ & $\begin{array}{c}28 \\
\text { days }\end{array}$ \\
\hline 0.42 & 0 & 105 & 1748 & 29.7 & 34.5 \\
\hline 0.40 & 1.0 & 105 & 1765 & 30.4 & 35.7 \\
\hline - , ro & 1.5 & 100 & 1775 & 30.7 & 36.9 \\
\hline 0.30 & r.0 & 98 & 1787 & 32.2 & 37.0 \\
\hline$\cdot, r V$ & 2.5 & 100 & 1800 & 33.4 & 39.0 \\
\hline$\cdot, Y_{0}$ & 3.0 & 100 & 1815 & 34.5 & 41.6 \\
\hline 0.23 & 3.0 & 105 & 1808 & 33.1 & 40.7 \\
\hline
\end{tabular}

Table 4. Details of trial mix with various dosages of silica fume

\begin{tabular}{|c|c|c|c|c|c|}
\hline $\begin{array}{c}\text { Silica fume } \\
(\%)\end{array}$ & $\begin{array}{c}\text { w/c } \\
\text { Ratio }\end{array}$ & $\begin{array}{c}\text { Slump } \\
\text { replacement } \\
\text { by Weight of } \\
\text { Cement) }\end{array}$ & $\begin{array}{c}\text { Oven } \\
\text { Dry } \\
\text { Density } \\
\mathrm{kg} / \mathrm{m}^{3}\end{array}$ & \multicolumn{2}{|c|}{$\begin{array}{c}\text { Compressive } \\
\text { Strength } \\
(\mathrm{MPa})\end{array}$} \\
\cline { 5 - 7 } & & $\begin{array}{c}7 \\
\text { day s }\end{array}$ & $\begin{array}{c}28 \\
\text { days }\end{array}$ \\
\hline 0 & 0.25 & 100 & 1815 & 34.5 & 41.6 \\
\hline 5 & 0.25 & 100 & 1818 & 35.1 & 45.8 \\
\hline 8 & 0.25 & 98 & 1823 & 38.9 & 46.5 \\
\hline 10 & 0.25 & 95 & 1828 & 40.0 & 47.0 \\
\hline
\end{tabular}

\subsection{Fresh density}

The fresh densities of HPLWAC are listed in Table 5 Results indicate that concrete reinforced with plastic fiber has lower fresh density compared with the plain concrete. The inclusion of steel fibers $(0.25 \%$ volume fraction) in double hybrid fiber concrete mix $\left(\mathrm{MAH}_{4}\right)$ increases the fresh density relative to concrete mix reinforced with plastic fiber (MAP) but it is still lower than that for plain concrete mix. The high volume fraction of steel fiber $(0.5 \%)$ in triple hybrid fiber reinforced concrete mix $\left(\mathrm{MAH}_{5}\right)$ explains highest fresh density. This is because of the low specific gravity of plastic fiber and the high specific gravity of steel fiber.

\subsection{Ovendry density}

The oven dry density of HPLWAC mixes prepared in this work is shown in Table 5. The inclusion of plastic fiber also causes a reduction in oven dry density of HPLWAC containing artificial LWA (mix MAP). Concrete specimens reinforced with double hybrid fibers show increase in densitites compared with those containing mono plastic fiber with the same total volume fraction but it is lower than plain specimens. The high volume fraction of steel fiber $(0.5 \%)$ in triple hybrid fiber reinforced concrete mix $\left(\mathrm{MAH}_{5}\right)$ gives concrete with highest dry density. This is due to the high density of steel fibers used as compared to plastic fiber.

Table 5. Workability and density for HPLWAC

\begin{tabular}{|c|c|cc|c|c|}
\hline Mix & $\begin{array}{c}\text { Slump } \\
\text { cone } \\
(\mathrm{mm})\end{array}$ & \multicolumn{2}{|c|}{$\begin{array}{c}\text { Inverted } \\
\text { slump } \\
\text { cone } \\
\text { Sec. }\end{array}$} & $\begin{array}{c}\text { Fresh } \\
\text { density } \\
\left(\mathrm{kg} / \mathrm{m}^{3}\right)\end{array}$ & $\begin{array}{c}\text { Oven Dry } \\
\text { density } \\
\left(\mathrm{kg} / \mathrm{m}^{3}\right)\end{array}$ \\
\hline MAR & 95 & 18 & -- & 1935 & 1828 \\
\hline MAP & 85 & 105 & --- & 1923 & 1821 \\
\hline $\mathrm{MAH}_{4}$ & 80 & 120 & 2 & 1930 & 1823 \\
\hline $\mathrm{MAH}_{5}$ & 65 & 120 & 6 & 1950 & 1835 \\
*The distance from top of concrete level to the top of cone is recorded \\
when the elapsed time is more than 120sec. \\
**Equilibrium density is equal to oven dry density plus $50 \mathrm{~kg} / \mathrm{m}^{3}$ \\
according to ASTM C567-05a[20].
\end{tabular}

\subsection{Compressive Strength}

The compressive strength development with age for all HPLWAC mixes are listed in Table [6]. Generally, the compressive strength increases with age for all concrete specimens. The compressive strength of concrete specimens containing artificial LWA and reinforce with mono plastic fiber at 7, 28, 60 and 90 days decreases by about $6.2 \%, 8.8 \%, 12.6 \%$ and $13.4 \%$ respectively relative to plain concrete (without fiber). This may be attributed to the high content of air and the presence of voids which reduce the compressive strength of concrete. Concrete specimens reinforced with double hybrid fibers $\left(\mathrm{MAH}_{4}\right)$ show higher compressive strength than those reinforced with mono plastic fiber (MAP), but it is still less than those for plain concrete specimens. This is attributed to the inclusion of steel fibers that slightly increases the compressive strength of concrete. The inclusion of triple hybrid fiber in HPLWAC $\left(\mathrm{MAH}_{5}\right)$ slightly improves the compressive strength relative to the plain concrete specimen (MAR).

Table 6. Compressive strength for HPLWAC

\begin{tabular}{|c|c|c|c|c|}
\hline Mix & \multicolumn{4}{|c|}{ Compressive strength (MPa) } \\
\cline { 2 - 5 } symbol & $\begin{array}{c}7 \\
\text { days }\end{array}$ & $\begin{array}{c}28 \\
\text { days }\end{array}$ & $\begin{array}{c}60 \\
\text { days }\end{array}$ & $\begin{array}{c}90 \\
\text { days }\end{array}$ \\
\hline
\end{tabular}




\begin{tabular}{|c|c|c|c|c|}
\hline MAR & 40.0 & 47.0 & 51.8 & 53.5 \\
\hline MAP & 37.7 & 43.2 & 46.0 & 47.2 \\
\hline MAH $_{4}$ & 39.0 & 45.6 & 48.4 & 49.2 \\
\hline MAH $_{5}$ & 41.8 & 48.5 & 53.9 & 54.8 \\
\hline
\end{tabular}

\subsection{Ultrasonic pulse velocity}

The UPV test is used to estimate the uniformity and quality of HPLWAC. The results of UPV for HPLWAC in Table 7 are in the range of $4.22-4.65 \mathrm{~km} / \mathrm{sec}$. These values represent the good quality of concrete specimens prepared in this investigation [32].

Table 7. Ultrasonic pulse velocity for HPLWAC

\begin{tabular}{|c|c|c|c|c|}
\hline \multirow{2}{*}{$\begin{array}{c}\text { Mix } \\
\text { symbol }\end{array}$} & \multicolumn{4}{|c|}{ UVP $(\mathrm{km} / \mathrm{sec})$} \\
\cline { 2 - 5 } & $\begin{array}{c}7 \\
\text { days }\end{array}$ & $\begin{array}{c}28 \\
\text { days }\end{array}$ & $\begin{array}{c}60 \\
\text { days }\end{array}$ & $\begin{array}{c}90 \\
\text { days }\end{array}$ \\
\hline MAR & 4.40 & 4.51 & 4.57 & 4.61 \\
\hline MAP & 4.22 & 4.34 & 4.45 & 4.53 \\
\hline $\mathrm{MAH}_{4}$ & 4.29 & 4.41 & 4.48 & 4.60 \\
\hline $\mathrm{MAH}_{5}$ & 4.35 & 4.53 & 4.60 & 4.65 \\
\hline
\end{tabular}

\subsection{Splitting tensile strength}

The development of splitting tensile strength with age for HPLWAC containing artificial lightweight aggregate is shown in Table 8 and Fig. 1. The results demonstrate that the inclusion of mono plastic fibers causes an increase in splitting tensile strength relative with plain concrete. The percentages of increase in splitting tensile strength are $20.8 \%, 31.9 \%, 36.4 \%$ and $41 \%$ at ages $7,28,60$ and 90 days age respectively as compared to the plain concrete specimen. This is because the action of fiber in arresting the cracks [ $\mathrm{V}]$. All hybrids fiber reinforced HPLWAC $\left(\mathrm{MAH}_{4}\right.$ and $\mathrm{MAH}_{5}$ ) demonstrate higher splitting tensile strength compared with concrete mix reinforced with mono plastic fiber (MAP). The maximum splitting tensile strength of HPLWAC with artificial aggregate is recorded for concrete specimen reinforced with triple hybrid fiber $\left(\mathrm{MAH}_{5}\right)$. The percentages of increase in splitting tensile strength for specimen reinforced with triple hybrid fiber are $34.6 \%, 56 \%, 63.6 \%$ and $68.1 \%$ for 7, 28, 60 and 90 days age respectively compared to the plain concrete specimen (MAR). This is because of the synergy between macro and micro fiber in arresting crack.

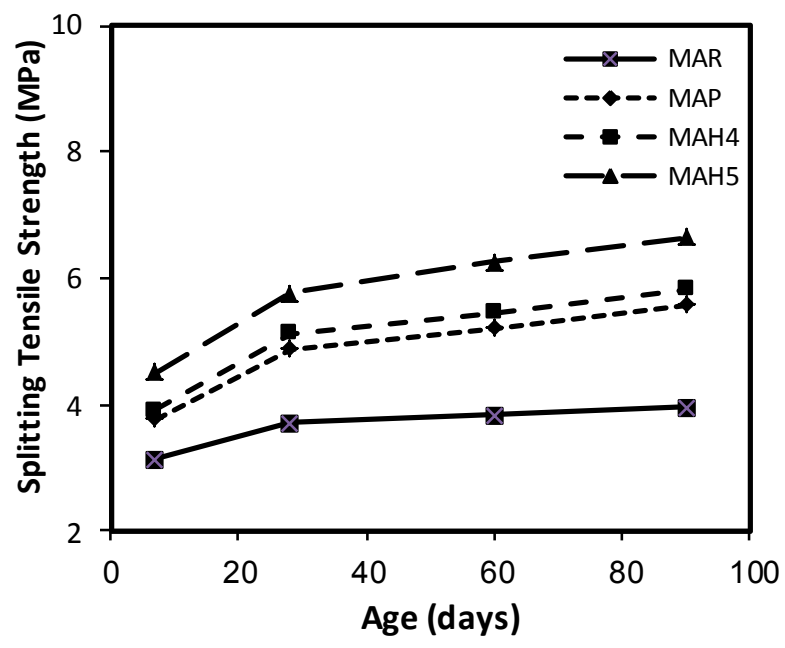

Fig.1. Splitting tensile strength development with various ages for lightweight concrete specimens.

Table 8. Splitting tensile strength for HPLWAC

\begin{tabular}{|c|c|c|c|c|}
\hline \multirow{2}{*}{$\begin{array}{c}\text { Mix } \\
\text { Symbol }\end{array}$} & \multicolumn{4}{|c|}{ Splitting Tensile Strength (MPa) } \\
\cline { 2 - 5 } & $\begin{array}{c}7 \\
\text { Days }\end{array}$ & $\begin{array}{c}28 \\
\text { Days }\end{array}$ & $\begin{array}{c}60 \\
\text { Days }\end{array}$ & $\begin{array}{c}90 \\
\text { Days }\end{array}$ \\
\hline MAR & 3.12 & 3.70 & 3.82 & 3.95 \\
\hline MAP & 3.77 & 4.88 & 5.21 & 5.57 \\
\hline $\mathrm{MAH}_{4}$ & 3.92 & 5.13 & 5.46 & 5.83 \\
\hline $\mathrm{MAH}_{5}$ & 4.50 & 5.77 & 6.25 & 6.64 \\
\hline
\end{tabular}

\subsection{Flexural tensile strength (modulus of rupture)}

The influence of fiber on flexural strength is listed in Table 9 and Fig. 2. The results demonstrate that the addition of fibers to HPLWAC increases the flexural strength for both mono and hybrid (double and triple) fiber reinforced concrete specimens compared to plain concrete specimens. The results of HPLWAC containing artificial LWA indicate that the inclusion of mono plastic fibers shows increase in flexural strength compared with reference concrete. The percentages of increase in flexural strength for concrete mix reinforced with mono plasticfiber (MAP) are 19.5\%, 37\%, 33.9\% and $34.2 \%$ at $7,28,60$ and 90 days age, respectively compared to plain concrete (MAR). This is due to the action of fiber that arrested the cracks. Hybrid fiber reinforced HPLWAC specimens $\left(\mathrm{MAH}_{4}\right.$ and $\left.\mathrm{MAH}_{5}\right)$ demonstrate higher flexural strength relative to concrete specimen with mono plastic (MAP). The highest flexural strength is recorded for concrete specimens reinforced with triple hybrid fiber $\left(\mathrm{MAH}_{5}\right)$. The percentages of increase in flexural strength for these specimens are $50.5 \%, 62.4 \%, 66.8 \%$ and $62.2 \%$ at 7,28 , 
60 and 90 days age respectively compared to plain concrete. This is due to the high tensile strength of steel fiber in triple hybrid fiber concrete mix and the synergy between micro and macro fibers in arresting micro and macro cracks respectively [33].

Table 9 Flexural strength of HPLWAC

\begin{tabular}{|l|r|c|c|c|}
\hline \multirow{2}{*}{$\begin{array}{l}\text { Mix } \\
\text { symbol }\end{array}$} & \multicolumn{4}{|c|}{ Flexural Strength (MPa) } \\
\cline { 2 - 5 } & $\begin{array}{c}7 \\
\text { days }\end{array}$ & $\begin{array}{c}28 \\
\text { days }\end{array}$ & $\begin{array}{c}60 \\
\text { days }\end{array}$ & $\begin{array}{c}90 \\
\text { days }\end{array}$ \\
\hline MAR & 4.10 & 4.87 & 5.18 & 5.47 \\
\hline MAP & 4.90 & 6.67 & 6.92 & 7.34 \\
\hline $\mathrm{MAH}_{4}$ & 5.25 & 6.83 & 7.36 & 7.85 \\
\hline $\mathrm{MAH}_{5}$ & 6.17 & 7.91 & 8.64 & 8.87 \\
\hline
\end{tabular}

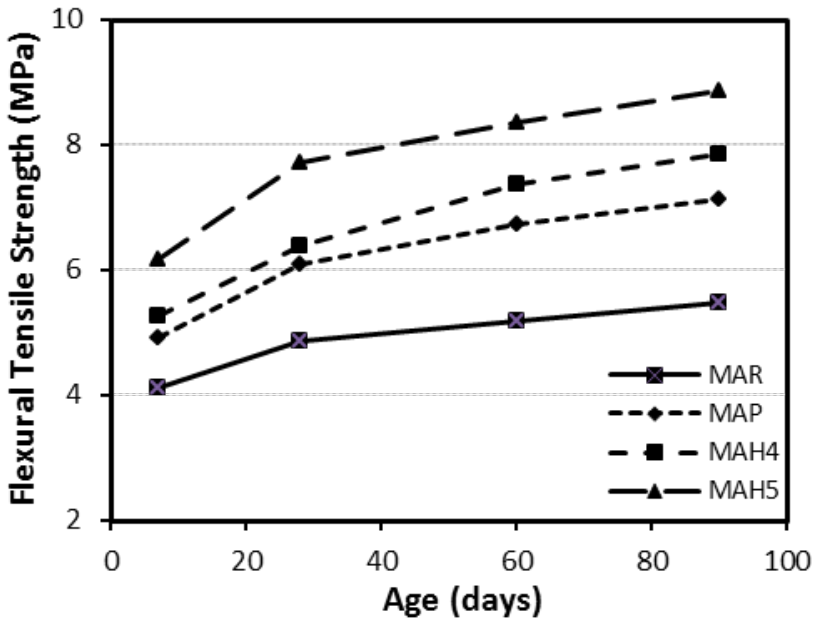

Fig. 2. Flexural tensile strength development with varies ages for lightweight concrete specimens.

\subsection{Static modulus of elasticity}

Static modulus of elasticity for all HPLWAC specimens is illustrated in Table 10. The results indicate that the inclusion of mono plastic fiber in concrete causes a decrease in modulus of elasticity by about $11.7 \%$ and $5.1 \%$ at 28 and 90 days age respectively compared with plain concrete. All hybrid fibers reinforced HPLWAC $\left(\mathrm{MAH}_{4}\right.$ and $\left.\mathrm{MAH}_{5}\right)$ show increase in modulus of elasticity in comparison with concrete specimen reinforced with mono plastic fiber (MAP). The highest modulus of elasticity is recorded for concrete specimen reinforced with triple fiber $\left(\mathrm{MAH}_{5}\right)$. This is due to the use of macro and micro steel fibers combined with other fibers (polypropylene fiber) in this specimen.

Table 10. Static modulus of elasticity of HPLWAC

\begin{tabular}{|c|c|c|}
\hline \multirow{2}{*}{$\begin{array}{c}\text { Mix } \\
\text { symbol }\end{array}$} & \multicolumn{2}{|c|}{ Static modulus of elasticity $(\mathrm{GPa})$} \\
\cline { 2 - 3 } & 28 Days & 90 Days \\
\hline MAR & 19.073 & 20.844 \\
\hline MAP & 17.081 & 19.520 \\
\hline $\mathrm{MAH}_{4}$ & 17.528 & 20.143 \\
\hline $\mathrm{MAH}_{5}$ & 20.436 & 21.024 \\
\hline
\end{tabular}

\subsection{Thermal Conductivity}

The results of the thermal conductivity of all HPLWAC specimens are shown in Table 11. Thermal conductivity of plain HPLWAC containing artificial lightweight aggregate is $0.9278 \mathrm{~W} /(\mathrm{m}$. K). Thermal conductivity of normal weight concrete is in the range of $1.98-2.94 \mathrm{~W} /(\mathrm{m} . \mathrm{K})$ depending on the type of aggregate used [34]. The low thermal conductivity of lightweight aggregate concrete is attributed to the presence of pores in lightweight aggregate that resist the heat flow through the concrete and affects the conductivity of the material. The low unit weight and thermal conductivity combined with the ability to cast in any desired shape enable this structural lightweight concrete to be suitable material for casting different thermal insulated structural members. The inclusion of mono plastic fiber in concrete specimens (MAP) causes a slight reduction in thermal conductivity. This reduction may be attributed to the low thermal conductivity of lightweight plastic fiber which increases the insulation property of the concrete specimens. Concrete specimens reinforced with hybrid (double and triple) fibers $\left(\mathrm{MAH}_{4}\right.$ and $\left.\mathrm{MAH}_{5}\right)$ show increase in thermal conductivity relative to plain concrete (MAR). This is because the high thermal conductivity of steel fiber.

\subsection{Water absorption}

The results of water absorption for HPLWAC specimens are listed in Table 11. The water absorption of all HPLWAC specimens are less than 10 percent by weight. This shows the good quality of HPLWAC specimens prepared in this work [32]. Also, HPLWAC specimens with artificial lightweight aggregate reinforced with mono or hybrid fibers indicate a decrease in water absorption relative with plain concrete specimen (MAR). This is because of the role of fibers which effectively increases the crack resistance that reduces the permeability of concrete.

Table 11. Thermal conductviy and water absorbtion of HPLWAC

\begin{tabular}{|c|c|c|}
\hline $\begin{array}{l}\text { Mix } \\
\text { symbol }\end{array}$ & $\begin{array}{c}\text { Water absorption } \\
\text { at } 28 \text { days }(\%)\end{array}$ & $\begin{array}{c}\text { Thermal conductivity } \\
\text { at } 28 \text { days } \\
{[\mathrm{W} /(\mathrm{m} . \mathrm{k})]}\end{array}$ \\
\hline MAR & 5.85 & 0.9278 \\
\hline $\mathrm{MAP}$ & 5.74 & 0.9132 \\
\hline $\mathrm{MAH}_{4}$ & 5.57 & 0.9379 \\
\hline $\mathrm{MAH}_{5}$ & 5.34 & 0.9987 \\
\hline
\end{tabular}

\section{Conclusions}

From the experimental results presented in this work, the following conclusions can be drawn:

[1] The produced sustainable lightweight aggregate concrete containing artificial LWA has a 
compressive strength of $47 \mathrm{MPa}$ and oven dry density of $1828 \mathrm{~kg} / \mathrm{m}^{3}$ at 28 days age.

[2] The addition of plastic fiber causes a reduction in oven dry density, while steel fiber causes increses in oven dry density. The addition of hybrid fiber (double and triple) shows increase in densitites compared with specimens containing mono plastic fiber with the same total volume fraction.

[3] The compressive strength of concrete specimens at different ages decreases with the addition of mono plastic fiber in the range from $(6 \%-13 \%)$, while the inclusion of double and triple hybrid fiber ( mixes $\mathrm{MAH}_{4}$ and $\mathrm{MAH}_{5}$ ) slightly improves the compressive strength relative to the plain concrete specimens.

[4] The inclusion of mono plastic fibers causes an increase in splitting tensile strength compared to plain concrete. Double and triple hybrid fiber reinforced specimens $\left(\mathrm{MAH}_{4}\right.$ and $\left.\mathrm{MAH}_{5}\right)$ show higher splitting tensile strength compared with specimens reinforced with mono plastic fiber (MAP).

[5] Mono plastic fibers show increase in flexural strength compared with plain concrete. Hybrid fiber reinforced specimens $\left(\mathrm{MAH}_{4}\right.$ and $\left.\mathrm{MAH}_{5}\right)$ show higher flexural strength relative to specimens reinforced with mono plastic fiber (MAP).

[6] The inclusion of mono plastic fiber in concrete specimens causes a decrease in modulus of elasticity. Double and triple hybrid fiber reinforced concrete specimens $\left(\mathrm{MAH}_{4}\right.$ and $\left.\mathrm{MAH}_{5}\right)$ show slight increase in modulus of elasticity in comparison with specimens reinforced with mono plastic fiber (MAP). The highest modulus of elasticity is recorded for specimens reinforced with triple hybrid fiber reinforced specimens $\left(\mathrm{MAH}_{5}\right)$.

[7] Thermal conductivity of plain specimens is 0.9278 $\mathrm{W} /(\mathrm{m} . \mathrm{K})$, while for specimens reniforecd with mono plastic fibers it is slightly lower. Specimens reinforced with double and triple hybrid fiber $\left(\mathrm{MAH}_{4}\right.$ and $\left.\mathrm{MAH}_{5}\right)$ show higher thermaal conductivity relative to both plain and plastic fiber reinforced specimens.

[9] The water absorption of all HPLWAC specimens reinforced with mono and hybrid fibers decreases compared with plain specimens.

\section{References}

1. Eurocode No.2, part I, General Rules and Rules for Buildings, Final Text,( October 1991)

2. Hoff, G.C., US Army Corps of Engineers, Engineer Research and Development Center, (August, 2002).

3. De Gennaro, R., Cappelletti, P., Gerri, G., De Gennaro, M., Doudi, M., and Langella, A., Applied Clay Science, Vol. 28, No. 1, pp.309-319, (2005)

4. Chi, J.M., Huang, R., Yang, C.C., and Chang, J.J., Cement and Concrete Composites,Vol.25, Issue 2, pp.197-205,(2003).

5. Cabral, A., Schalch, V., Molin, D., and Ribeiro, J., Construction and Building Materials, Vol. 24, pp. 421-430, (2010)

6. Sabin, G. M., Taylor and Francis Group, (201).
7. Daneti, S.B., and Wee, T. H., Magazine of Concrete Research, Vol.63, Issue 11, pp.871-881, (2011).

8. Widodo, S., Satyarno, I. and Tudjono, S., Civil Engineering, Vol. 23, No. 8, pp. 1211-1219, (2011).

9. Iraqi Standard, NO.5, "Portland Cement", The Central Organization for Standardization and Quality Control, (1984), (in Arabic).

10. Iraqi Specification, No.45, "Aggregate from Natural Sources for Concrete and Constructions", (1980), (in Arabic).

11. Khalil, W. I., Ahmed, H. K., and Hussein, Z. M, $17^{\text {th }}$ International Conference on Building Science and Engineering, Berlin Germany Conference, Sep 14-15, Vol. 19, No.(9) Part IV, (2015).

12. ASTM C330-03, "Standard Specification for Lightweight Aggregates for Structural Concrete" Annual Book of ASTM Standards, Vol.04-02, Concrete and Aggregates, United States, (2003).

13. ASTM C127, "Standard Test Method for Density Relative Density (Specific Gravity) and Adsorption of Coarse Aggregate", Annual Book of ASTM Standards, Vol. 04.02, pp. 68-73, (2004).

14. ASTM C29/C29M, "Standard Test Method for Bulk Density (Unit Weight) and Voids in Aggregate", Annual Book of ASTM Standards, Vol. 04.02, pp. 1- 4, (2004).

15. BS 812, Part 110, "Method for Determination of Aggregate Crushing Value (ACV)", British Standards Institution, pp. 8, (1990).

16. BS 3797, "Specification for Lightweight Aggregates for Masonry Units and Structural Concrete", British Standards Institution, pp. 2, (1990).

17. ASTM C494/C494M, "Standard and Specification for Chemical Admixtures for Concrete", Annual Book of ASTM Standards, Vol. 04.02, pp. 271279, (2004).

18. ASTM C1240 "Standard Specifications for Silica Fume Used in Cementitious Mixtures", Annual Book of ASTM Standards, Vol.04, pp. 200-208, (2007).

19. ASTM C143/C143M-03, "Standard Test Methods for Slump of Hydraulic-Cement Concrete", Annual Book of ASTM Standards, Vol. 04.02, pp. 95-98, (2004).

20. ASTM C567, "Standard Test Methods for Determination Density of Structural Lightweight Concrete", Annual Book of ASTM Standards, Vol. 04.02, pp. 302-304, (2004).

21. ASTM C955/C995, "Standard Test Methods for Time of Flow of Fiber-Reinforced Concrete through Inverted Slump Cone ", Annual Book of ASTM Standards, Section 6, Vol. 04.02, (2001).

22. BS. 1881, Part 116, "Method for Determination of Compressive Strength of Concrete Cubes", British Standards Institution, 1881; pp. 3, (1989).

23. ASTM C496/C496M, "Standard Test Methods for Splitting Tensile Strength of Cylindrical", Annual Book of ASTM Standards, Vol. 04.02, pp. 283287, (2004).

24. ASTM C78-02, "Standard Test Method for Flexural Strength of Concrete (Using Simple Beam with 
Third-Point Loading)", Annual Book of ASTM Standards, American Society for Testing and Materials, Vol. 04-02, pp.1-3, (2007).

25. ASTM C469, "Standard Test Methods for Static Modulus of Elasticity and Poisson's Ratio of Concrete in Compression", Annual Book of ASTM Standards, Vol. 04.02, pp. 256-259, (2004).

26. ASTM C597, "Standard Test Methods for Pulse Velocity through Concrete", Annual Book of ASTM Standards, Vol. 04.02, pp. 310-313, (2004).

27. ASTM C642," Standard Test Method for Density, Absorption, and Voids in Hardened Concrete", Annual Book of ASTM Standards Volume: 04.02, (2013).

28. ACI Committee 211, "Standard Practice for Selecting Proportion for Structural Lightweight Concrete", ACI Manual of Concrete Practice, Part 1, pp. $211-$ 218, (2004).
29. Topcu, I.B., and Canbaz, M., Construction and Building Materials, Vol.21, Issue 7, pp.14861491, (2007).

30. Chen, B., and Liu, J., Cement and Concrete Research, Vol.35, No.6, pp.2458-2464, (2005).

31. Libre, N.A., Shekarchi, M., Mahoutian, M., and Soroushian, P., C construction and Building Materials, Vol. 25, No.12, pp. 2458-2464, (2011).

32. Neville, A. M., "Properties of Concrete", Fourth and final edition, Longman Group, Ltd., (2005).

33. Kim, D. J., Park, S.H., Ryu, G.S. and Koh, K.T., Journal of Construction and Building Materials, Vol.25, No.5, pp.4144- 4155, (2011).

34. Milovanovic, B., Pecur, I.B., and Gabrijiel, I., Novel Development and Innovation in Cementitious Materials, 12-13, Imperial College, London, United Kingdom, pp.1-5. ( 2011). 